The Chittagong Univ. J. Sci. 41(1) : 1-20, 2019

DOI: https://doi.org/10.3329/cujs.v41i1.51912

\title{
Possible Corruption Risks to Successful Implementation of REDD+ in Bangladesh
}

\author{
Md. Danesh Miah* and S. M. Raihan Abedin \\ Institute of Forestry \& Environmental Sciences, University of Chittagong, \\ Chittagong 4331, Bangladesh \\ *Corresponding author: danesh@cu.ac.bd; dansmiah@gmail.com
}

\begin{abstract}
Deforestation and forest degradation are the important causal agents to global climate change. REDD+ (Reducing Emissions from Deforestation and Forest Degradation along with conservation and enhancement of forest carbon stocks and sustainable management of forest) is a recently adopted global initiative to mitigate global climate change by conserving the forests and its carbon. Bangladesh is still in the preparatory phase of the REDD+ program. Assessing the potential risks of corruption is important to the setting up of strategies of REDD+ implementation. So, a study was conducted in the Madhupur, Sreemangal and Rangamati forest areas to assess these risks. The study was conducted through three types of surveys and interviews. It was found that there is a chance of potential corruption risks while implementing REDD+ program in Bangladesh. Political leaders and other powerful groups may manipulate the policy making and development strategies of REDD+. Financial management, benefit sharing and procurement management in the REDD+ program should be considered in the corruption risks analysis. There is a chance of diversion or embezzlement of REDD+ funds, laundering of money and elite capture of REDD+ benefits. Over estimation of costs and collusions in the bidding may also occur while implementing REDD+. For the successful and
\end{abstract}


2 Md. Danesh Miah and S. M. Raihan Abedin

transparent implementation of REDD+, this possible risks should be taken into consideration. This study can be partially useful to fixing up the REDD+ strategies in Bangladesh.

Keywords: Service delivery, Carbon and non-carbon benefit, Financial management, Procurement management, Safeguards

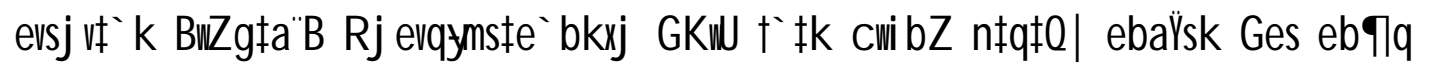

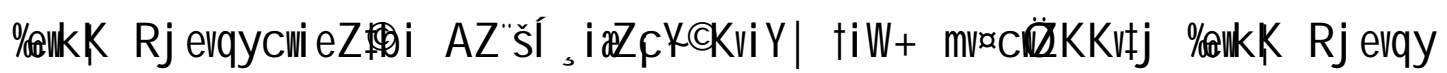

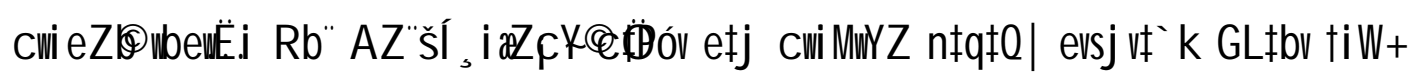

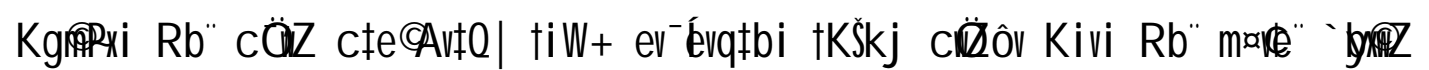

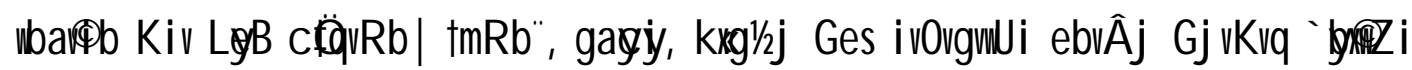

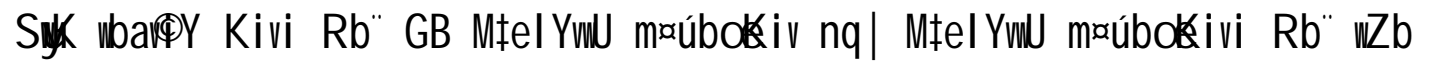

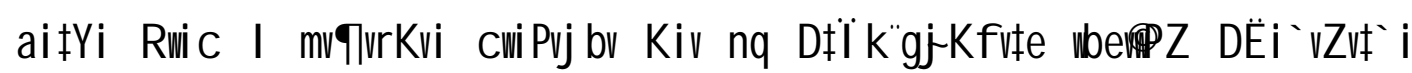

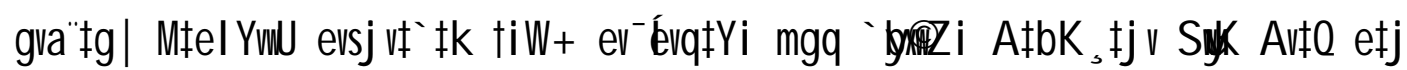

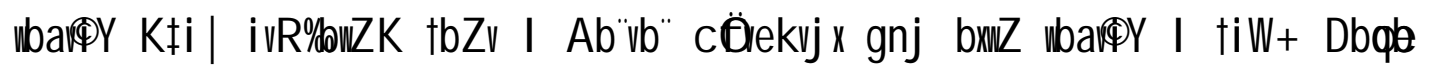

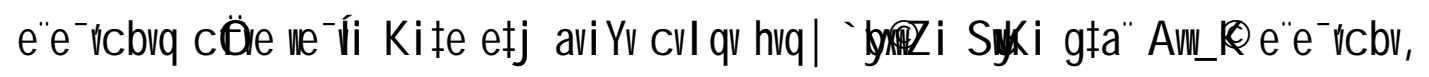

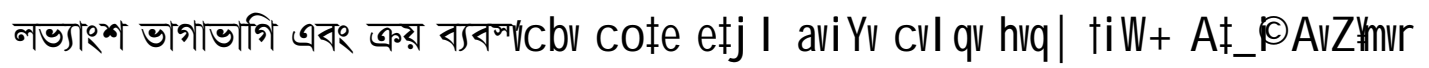

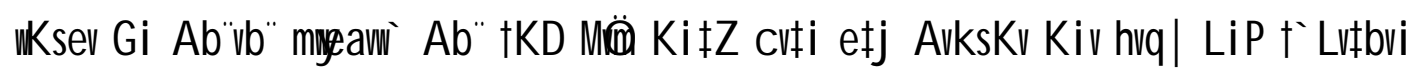
切代 A函

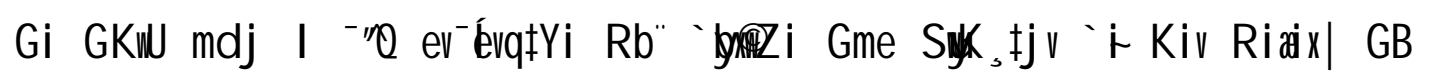

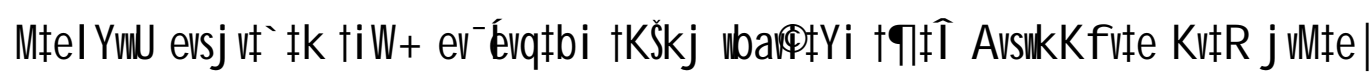
Introduction 
Reducing Emissions from Deforestation and Forest Degradation, conservation and enhancement of forest carbon stocks, and sustainable management of forests (REDD+) has become an important topic in the field of climate change mitigation in developing countries [1]. Deforestation and forest degradation is now a major root-cause of global greenhouse gas (GHG) emissions [2]. The main objective of REDD+ is to involve developing countries in reducing global GHG emissions through the reduction of deforestation and forest degradation by giving financial incentives [3]. Bangladesh has joined the UN-REDD program in August 2010 and then prepared a REDD+ readiness roadmap with the support of UNDP [1]. To successfully implement the REDD+ program in Bangladesh, analyzing the role of governance is necessary $[4,5]$.

About $17 \%$ of the anthropogenic global GHG emissions is caused by deforestation and forest degradation [6,7] where tropical countries contribute a large amount [2]. In this context, REDD+ is offering to the tropical countries biodiversity and carbon-rich mechanism to conserve the biodiversity as a co-benefit of maintaining forests and the stored carbon [8-10]. Illegal forest activities and corruptions in the forestry sector are the major governance issues behind the causes of deforestation and forest degradation in Bangladesh [11-13]. Logging operators offer bribes to the forestry officials to issue illegal logging permits [14], to harvest timber without any permits [15], to transport the illegally logged timber [16] which has a large contribution to deforestation and forest degradation.

The rate of deforestation in Bangladesh was 8,000 hectares per year (ha/yr) in 1980 which at present increased to $37,700 \mathrm{ha} / \mathrm{yr}$ [17]. The per capita forestland of 
4 Md. Danesh Miah and S. M. Raihan Abedin

Bangladesh is approximately 0.02 ha where the existing natural forests are decreasing at an alarming rate of $2.1 \%$ to $3.3 \%$ per year [18]. The primary causes behind the deforestation and forest degradation are illegal logging, encroachment, grazing, fire, land use conflict, over extraction of the forest products, unplanned development activities, corruption inside the FD, etc. [19-23]. Though it is possible to gain the benefits from forest conservation through REDD+ program, there is a chance of some corruption risks while implementing REDD+ in developing countries [24]. However, the knowledge pool lacks the understanding of these risks, which are essential for fixing strategies for REDD+ implementation in Bangladesh. The general objective of this study was to assess the corruption risks of REDD+ implementation in Bangladesh. The specific objectives of the study were to find out the risks while developing policies and measures for REDD+; to find out the risks of procurement and financial management inside REDD+; to find out the risks of benefit sharing and service delivery inside REDD+. This study will be partially helpful to bridge over the knowledge gaps of the possible corruption risks for the successful implementation of REDD+ in Bangladesh.

\section{Materials and Methods}

To address the objectives, the study was accomplished by Online Survey, Focus Group Discussion (FGD) and Key Informants Interview (KII). The study was conducted during the period of June 2013 through February 2014. The online survey used the 'Survey Monkey' professional version. The survey requested 200 respondents for the online survey. Among them, the Survey Monkey received only 68 responses. There were $88 \%$ male and $12 \%$ female respondents in the online 
survey. The age classes of 20 to 35 and 36 to 50 years separately represented the most respondents as $47 \%$ and $46 \%$, respectively.

There were $2 \%$ respondents below 20 years old, $5 \%$ between 51 to 65 years old and $2 \%$ above 65 years old. The online survey considered respondents from different work class and institutions, i.e., Local Government, Business Sector, International Institutions, Non-Government Organizations, Indigenous Peoples' Organization, Academic Institutions, FD, Civil Society, Government Administration, Sawmill, Furniture Industry, and Anti-corruption Agency. The highest number (16\%) of respondents in online survey was from International Institution/Groups and the lowest number (1\%) was in Local Governments. About $26 \%$ respondents had the experiences of working over 10 years. The working experience of over five years was of $4 \%$ respondents. On the other hand, about $8 \%$ respondents had working experience of 3 to 5 years and other $8 \%$ had 1 to 3 years. There was no respondent who had a working experience of less than one year.

For FGD and KII, the study interviewed the people onsite in Madhupur, Sreemangal and Rangamati. The FGD considered four groups separately, i.e., timber traders, sawmill owners, furniture makers, and forest dependent people. The members in a group were in a range of 20-30. The total number of the FGD was 12. For KII, we considered the local journalist, academician, leader of the ethnic community, lawyer, NGO activist, and officer of the Bangladesh Anti-Corruption Commission. The total number of the key informant interviewees was 15 in the survey. For the study, all the selection of the respondents was purposive. 
6 Md. Danesh Miah and S. M. Raihan Abedin

\section{Results and Discussion}

\section{Strategic decisions when developing policies and measures for REDD+}

Developing policies and measures for REDD+ may have some critical issues. Powerful groups may manipulate, pressurize or interfere in policy-making and implementation. Politicians may influence the issuance of permits to accommodate friends, receive commissions or as owners of businesses. From the perception of the study, this was the major issue which had a maximum average rating of 4.02 on the scale of 5 (Figure 1). About $48 \%$ and $35 \%$ respondents choose this option as likely and highly likely to be happen, respectively (Table 1). Interpretation of the law favors vested interests, misleading or fraudulent claims on carbon rights and abuse of discretion with regard to whom the projects will be awarded. These are the other issues which have to be considered when developing policies and measures for REDD+ which had an average rating of 3.43, 3.36 and 3.64, respectively. Considering the stakeholders' view, it is clear that political leaders and other local powerful groups are the main risks of REDD+ project implementation in Bangladesh. To check these risks, REDD+ policies should be more transparent and accountable. According to the forest dependent communities in Madhupur, appropriate coordination between Forest Department (FD) and forest dependent people is necessary to promote integrity in forest governance system.

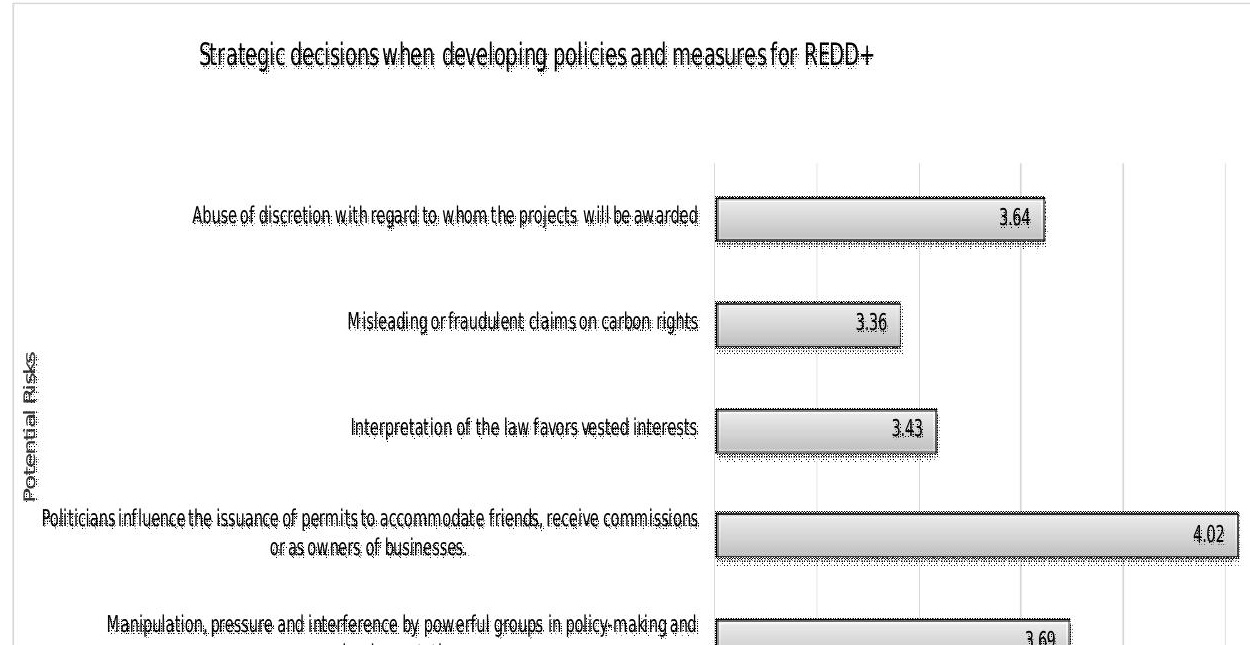


Possible Corruption Risks to Successful Implementation of REDD+ In Bangladesh 7

Figure 1: Average ratings of the potential risks when developing policies and measures for REDD+ in Bangladesh.

Table 1: Possibilities of the potential risks when developing policies and measures for REDD+ in Bangladesh.

\begin{tabular}{|c|c|c|c|c|c|}
\hline Potential Risks & $\begin{array}{c}\text { Not } \\
\text { Likely at }\end{array}$ & $\begin{array}{c}\text { Unlikely } \\
(\%)\end{array}$ & $\begin{array}{c}\text { Neutral } \\
(\%)\end{array}$ & $\begin{array}{c}\text { Likely } \\
(\%)\end{array}$ & $\begin{array}{c}\text { Highly } \\
\text { likely } \\
(\%)\end{array}$ \\
\hline
\end{tabular}




\begin{tabular}{|l|c|c|c|c|c|}
\hline $\begin{array}{l}\text { Manipulation, pressure and interference } \\
\text { by powerful groups in policy-making } \\
\text { and implementation }\end{array}$ & 7.4 & 7.4 & 20.4 & 38.9 & 25.9 \\
\hline $\begin{array}{l}\text { Politicians influence the issuance of } \\
\text { permits to accommodate friends, receive } \\
\text { commissions or as owners of businesses }\end{array}$ & 3.7 & 9.3 & 3.7 & 48.1 & 35.2 \\
\hline $\begin{array}{l}\text { Interpretation of the law favors vested } \\
\text { interests }\end{array}$ & 7.4 & 13 & 27.8 & 33.3 & 18.5 \\
\hline $\begin{array}{l}\text { Misleading or fraudulent claims on } \\
\text { carbon rights }\end{array}$ & 1.9 & 15.1 & 37.7 & 35.8 & 9.4 \\
\hline $\begin{array}{l}\text { Abuse of discretion with regard to whom } \\
\text { the projects will be awarded }\end{array}$ & 3.8 & 5.7 & 26.4 & 50.9 & 13.2 \\
\hline
\end{tabular}

\section{Performance management/service delivery}

In case of performance management and service delivery during the implementation of REDD+, there are some risks of abuses. Favoritism may have a great influence in the resolution of grievances and conflicts involving REDD+ programs and projects. In the study, $46 \%$ and $15 \%$ respondents choose this option as likely and highly likely to happen which had the maximum rating of 2.39 (Table $2 \&$ Figure 2). Abuse of discretion in the selection of personnel and improper selection of person to receive trainings were other two issues which had an average rating of 2.19 and 2.21, respectively which have to be considered as the main risks related to the performance management and service delivery in REDD+ (Figure 2). According to the timber traders, sawmill owners and furniture maker groups in 
Madhupur, lack of awareness and lack of proper understanding of the power of FD weakens forest governance system.

Table 2: Possibilities of the potential risks during performance management/ service delivery in REDD+ in Bangladesh.

\begin{tabular}{|l|c|c|c|c|c|}
\hline \multicolumn{1}{|c|}{ Potential Risks } & $\begin{array}{c}\text { Highly } \\
\text { Unlikely } \\
(\boldsymbol{\%})\end{array}$ & $\begin{array}{c}\text { Unlikely } \\
(\boldsymbol{\%})\end{array}$ & $\begin{array}{c}\text { Neutral } \\
(\boldsymbol{\%})\end{array}$ & $\begin{array}{c}\text { Likely } \\
(\boldsymbol{\%})\end{array}$ & $\begin{array}{c}\text { Highly } \\
\text { Likely } \\
(\boldsymbol{\%})\end{array}$ \\
\hline $\begin{array}{l}\text { Favoritism in the resolution of } \\
\text { grievances and conflicts involving } \\
\text { REDD+ programs and projects }\end{array}$ & 3.7 & 7.4 & 27.8 & 46.3 & 14.8 \\
\hline $\begin{array}{l}\text { Abuse of discretion in the selection of } \\
\text { personnel }\end{array}$ & 1.9 & 7.5 & 18.9 & 50.9 & 20.8 \\
\hline $\begin{array}{l}\text { Improper selection of person to } \\
\text { receive trainings }\end{array}$ & 1.9 & 3.8 & 32.1 & 37.7 & 24.5 \\
\hline
\end{tabular}

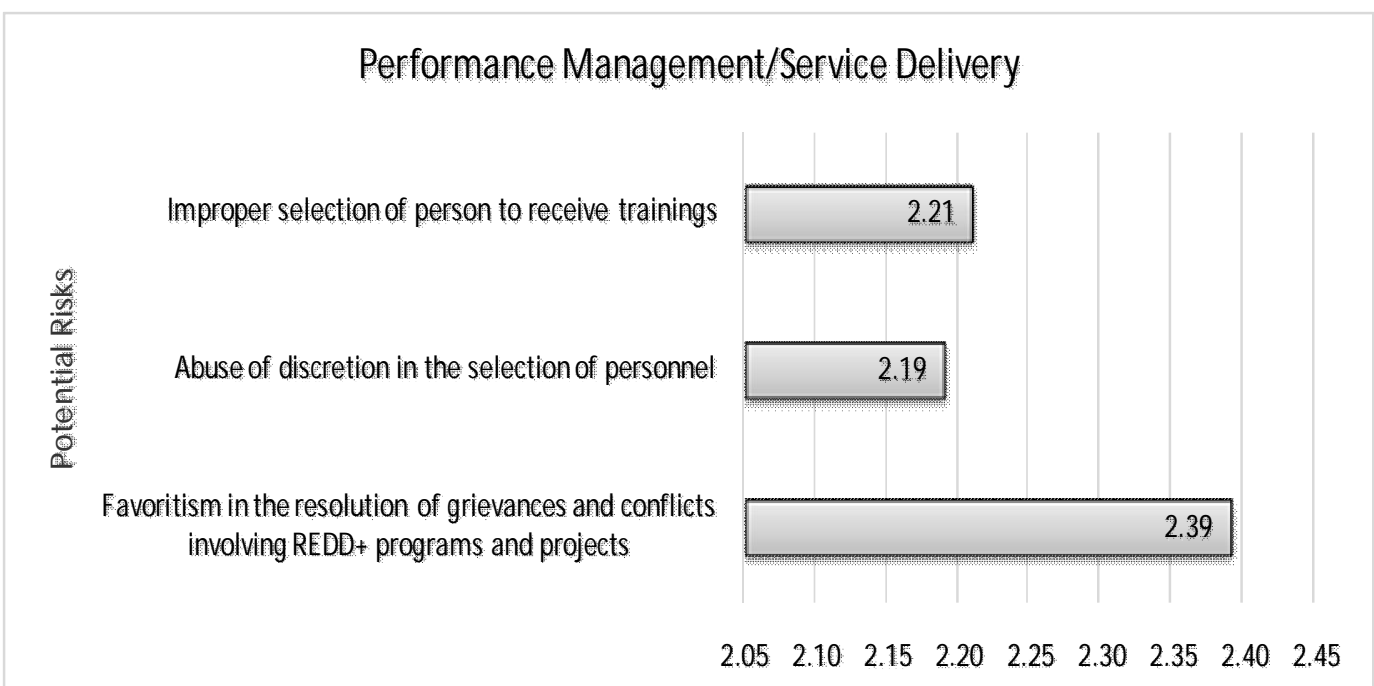


10 Md. Danesh Miah and S. M. Raihan Abedin

Figure 2: Average rating of the potential risks during performance management/ service delivery in Bangladesh.

\section{Measuring carbon and other non-carbon benefits of REDD+}

During implementation of REDD+, there are some risks when measuring carbon and non-carbon benefits. Implementation of REDD+ activities may produce fraudulent resource inventories and performance reporting. From the perception of the study this issue had an average rating of 3.22 (Figure 3). About 34\% respondents choose this option as neutral and $29 \%$ as likely to occur (Table 3 ). The other issue was manipulation of data on carbon and non-carbon reporting which had an average rating of 4 where $56 \%$ respondent choose this option as likely and $9 \%$ as highly likely to happen.

From the perception of the stakeholders' responses, it is clear that there is a lack of clarity on how much carbon and non-carbon benefits actually can be earned through REDD+ project. From the perception of the FGD with forest dependent community in Rangamati, it is found that forest officials don't handover the agreement papers to the participants in afforestation programs. 
Table 3: Possibilities of the potential risks during measuring carbon and other noncarbon benefits of REDD+ in Bangladesh.

\begin{tabular}{|l|c|c|c|c|c|c|}
\hline \multicolumn{1}{|c|}{ Potential Risks } & $\begin{array}{c}\text { Highly } \\
\text { Unlikely } \\
(\boldsymbol{\%})\end{array}$ & $\begin{array}{c}\text { Unlikely } \\
(\boldsymbol{\%})\end{array}$ & $\begin{array}{c}\text { Neutral } \\
(\boldsymbol{\%})\end{array}$ & $\begin{array}{c}\text { Likely } \\
(\boldsymbol{\%})\end{array}$ & $\begin{array}{c}\text { Highly } \\
\text { Likely } \\
(\boldsymbol{\%})\end{array}$ & $\begin{array}{c}\text { N/C } \\
(\boldsymbol{\%})\end{array}$ \\
\hline $\begin{array}{l}\text { Implementation of } \\
\text { REDD+ activities } \\
\text { produce fraudulent } \\
\text { resource inventories } \\
\text { and performance } \\
\text { reporting }\end{array}$ & 3.6 & 16.1 & 33.9 & 28.6 & 7.1 & 10.7 \\
\hline $\begin{array}{l}\text { Manipulation of data } \\
\text { on carbon and non- } \\
\text { carbon reporting }\end{array}$ & 5.5 & 16.4 & 7.3 & 56.4 & 9.1 & 5.5 \\
\hline
\end{tabular}

*N/C refers to No Comment

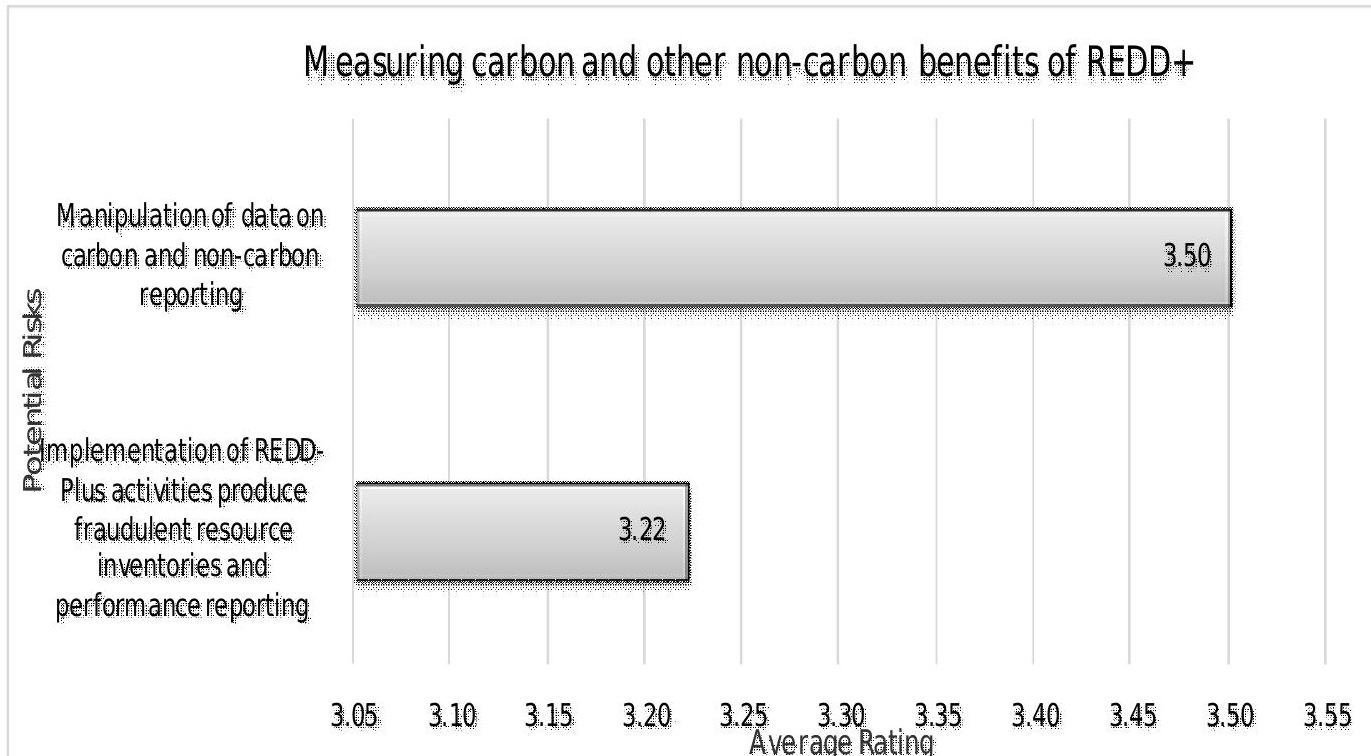


12 Md. Danesh Miah and S. M. Raihan Abedin

Figure 3: Average rating of the potential risks during measuring carbon and other non-carbon benefits of REDD+ in Bangladesh.

\section{Financial management and benefit sharing}

The main issue to be considered in case of financial management and benefit sharing during implementation of REDD+, is the diversion or embezzlement of REDD+ funds where embezzlement means any misappropriation of the responsibility of the property or funds legally assigned to someone in their formal status as an agent or representative. This issue had an average rating of 3.50 from the perception of our study (Figure 4). About 23\% respondents choose this issue as neutral and $46 \%$ as likely to happen (Table 4). The other two issues were laundering of money and other assets through the purchase and sale of carbon rights, and elite capture of REDD+ benefits which had an average rating of 3.22 and 3.38, respectively. About $46 \%$ respondents thought that there is a chance of diversion or embezzlement of REDD+ funds likely to take place. Considering the views of stakeholders in Bangladesh about the specific corruption risks of REDD+, it is clear that the greatest concern lies with diversion and embezzlement of funds, 
primarily by the local government, but also by other personnel engaged in REDD+ projects. According to the KII in Madhupur, selection of participants and extortion of money by forest officials from the participants of social forestry is the main issue in case of benefit sharing.

Table 4: Possibilities of the potential risks during financial management and benefit sharing of REDD+ in Bangladesh.

\begin{tabular}{|l|c|c|c|c|c|c|}
\hline \multicolumn{1}{|c|}{ Potential Risks } & $\begin{array}{c}\text { Highly } \\
\text { Unlikely } \\
(\%)\end{array}$ & $\begin{array}{c}\text { Unlikely } \\
(\%)\end{array}$ & $\begin{array}{c}\text { Neutral } \\
(\%)\end{array}$ & $\begin{array}{c}\text { Likely } \\
(\%)\end{array}$ & $\begin{array}{c}\text { Highly } \\
\text { Likely } \\
(\%)\end{array}$ & $\begin{array}{c}\text { N/C } \\
(\%)\end{array}$ \\
\hline $\begin{array}{l}\text { Diversion or embezzlement of } \\
\text { REDD+ funds }\end{array}$ & 3.6 & 12.5 & 23.2 & 46.4 & 10.7 & 3.6 \\
\hline $\begin{array}{l}\text { Laundering of money and } \\
\text { other assets through the } \\
\text { purchase and sale of Carbon } \\
\text { rights }\end{array}$ & 7.1 & 21.4 & 21.4 & 26.8 & 14.3 & 8.9 \\
\hline $\begin{array}{l}\text { Elite capture of REDD+ } \\
\text { benefits }\end{array}$ & 7.1 & 16.1 & 23.2 & 35.7 & 16.1 & 1.8 \\
\hline
\end{tabular}

*N/C refers to No Comment

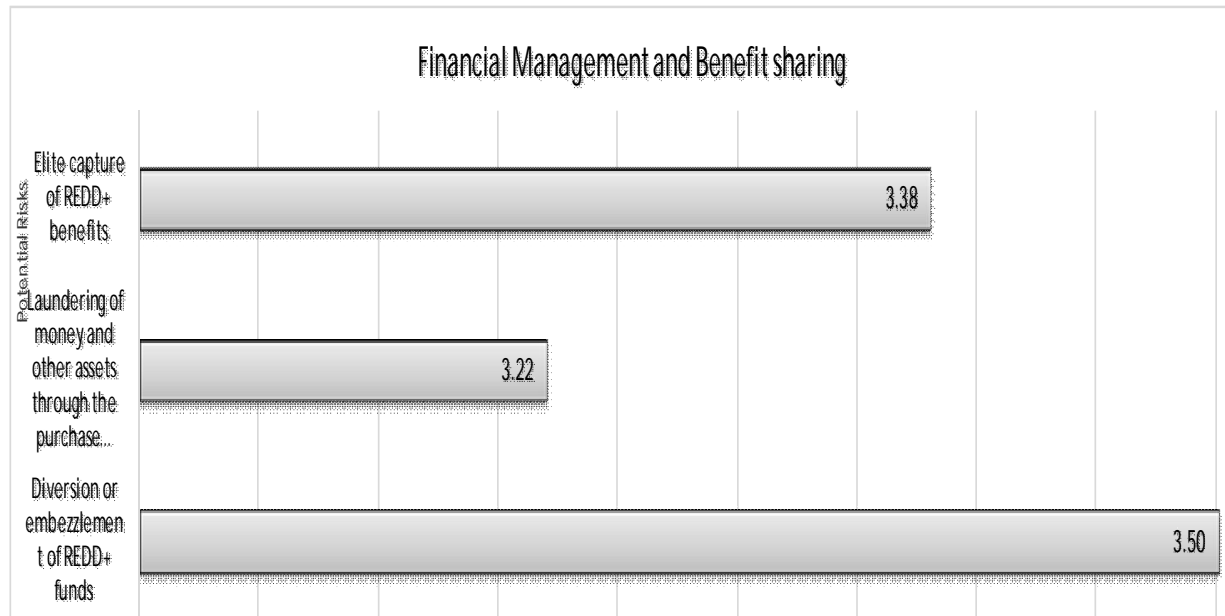


14 Md. Danesh Miah and S. M. Raihan Abedin

Figure 4: Average rating of the potential risks during financial management and benefit sharing of REDD+ in Bangladesh.

\section{Procurement management}

There may have some risks in procurement management during the implementation of REDD+ activities. Corruption may come at every stage of the procurement management process. There is a chance of overestimation of costs for equipment, supplies and materials. Politicians, investors and REDD+ implementers may create collusion in the bidding or approval of contracts. From the result of our study, overestimation of costs had an average rating of 3.50 and the other issue, collusion in the bidding or approval of contracts had an average rating of 3.82 (Figure 5). About 54\% respondents perceive that collusion between the politicians, investors and REDD+ implementers is likely to happen. About $32 \%$ respondents think that overestimation of costs is likely to occur (Table 5). According to the forest officials in Madhupur, tendering process of various FD projects is only circulated to a small number of potential bidders. The journalists from Sreemangal perceive that, training of forest officials on duties, transparency, values and accountability can mitigate these governance issues. 
Table 5: Possibilities of the potential risks during procurement management of REDD+ in Bangladesh.

\begin{tabular}{|l|c|c|c|c|c|c|}
\hline \multicolumn{1}{|c|}{ Potential Risks } & $\begin{array}{c}\text { Highly } \\
\text { Unlikely } \\
(\boldsymbol{\%})\end{array}$ & $\begin{array}{c}\text { Unlikely } \\
(\boldsymbol{\%})\end{array}$ & $\begin{array}{c}\text { Neutral } \\
(\boldsymbol{\%})\end{array}$ & $\begin{array}{c}\text { Likely } \\
\mathbf{( \% )}\end{array}$ & $\begin{array}{c}\text { Highly } \\
\text { Likely } \\
(\boldsymbol{\%})\end{array}$ & $\begin{array}{c}\text { N/C } \\
(\boldsymbol{\%})\end{array}$ \\
\hline $\begin{array}{l}\text { Overestimation of costs for } \\
\text { equipment, supplies and } \\
\text { materials }\end{array}$ & 1.8 & 19.6 & 23.2 & 32.1 & 19.6 & 3.6 \\
\hline $\begin{array}{l}\text { Collusion (of politicians, } \\
\text { investors and REDD+ } \\
\text { implementers) in the bidding } \\
\text { or approval of contracts }\end{array}$ & 0 & 12.5 & 12.5 & 53.6 & 19.6 & 1.8 \\
\hline
\end{tabular}

*N/C refers to No Comment 
Md. Danesh Miah and S. M. Raihan Abedin

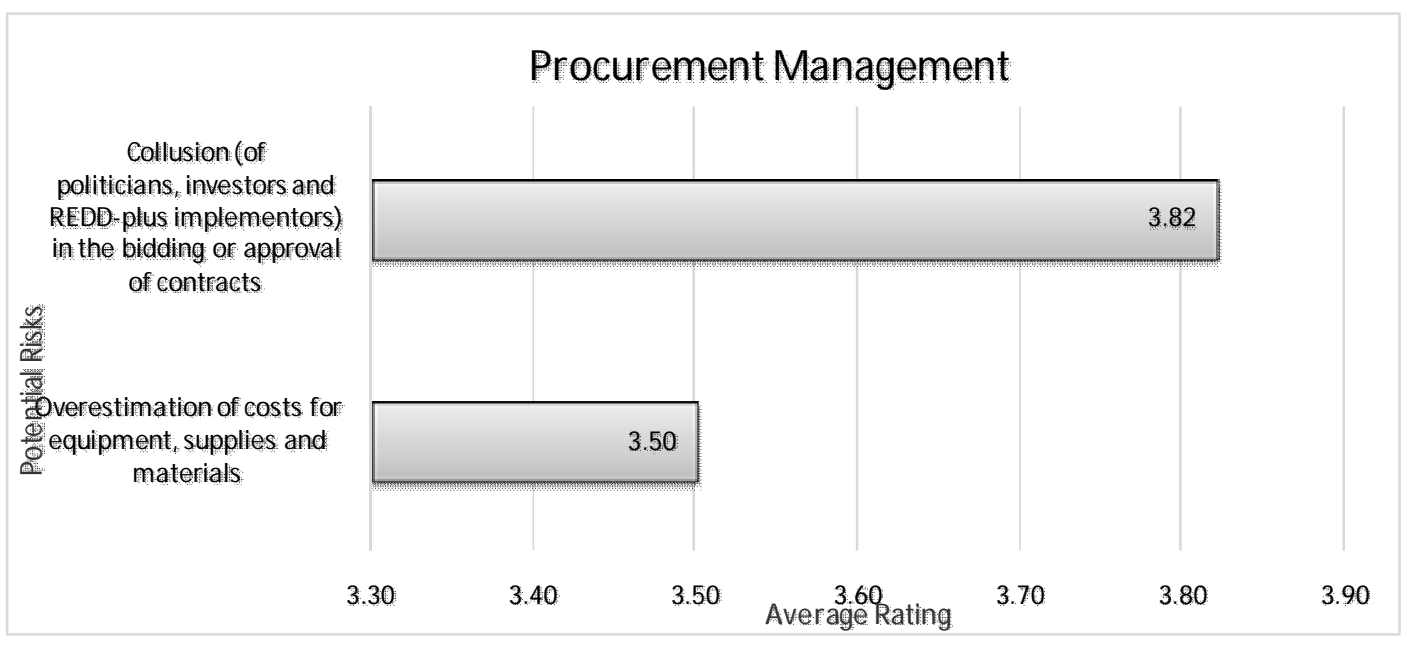

Figure 5: Average rating of the potential risks during procurement management of REDD+ in Bangladesh

\section{Safeguards}

Inaccurate information to deliberately limit effective engagement and decisionmaking power of certain stakeholders, particularly marginalized populations, such as, women, indigenous people and the poor can be a considerable issue as safeguards during implementation of REDD+. In the study, this issue had an average rating of 3.80 (Figure 6). There were some other issues such as fraud to deliberately designed weak system of information for environmental and social safeguards, bribery to overlook non-respect of safeguards, and extortion to release official information necessary to provide information on how safeguards are addressed and respected which had average rating of 3.62, 3.96 and 3.63, respectively. Here bribery refers to the act of giving someone's money, services or 
other inducements to motivate him or her to do something which is not legal. Fraud refers to an intentional hypocrisy which is done to get an illogical favor by giving or receiving deceitful or confusing information.

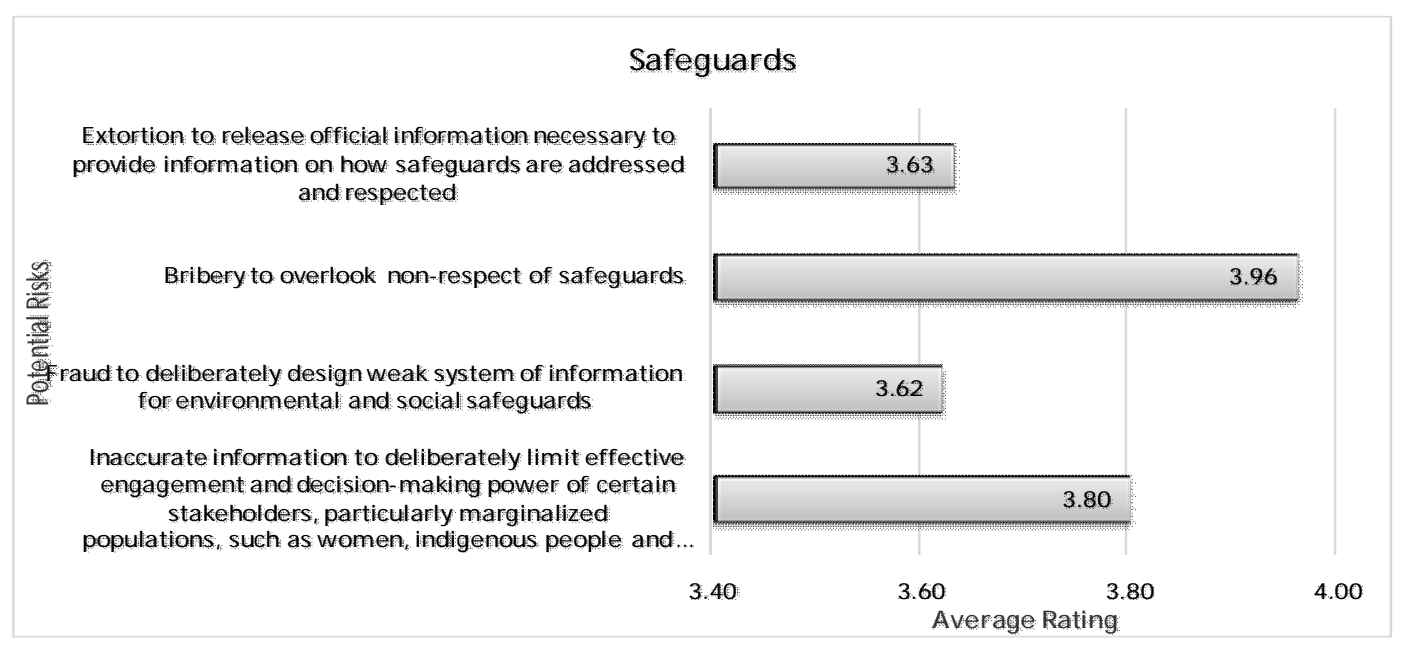

Figure 6: Average rating of the potential risks of safeguards in REDD+ implementation in Bangladesh.

\section{Conclusion}

The study revealed that there is a chance of potential corruption risks when implementing REDD+ in Bangladesh. Political leaders and other powerful groups may influence the policy development and performance management in REDD+. There is a chance of manipulation of data on carbon and non-carbon reporting and misleading and fraudulent claims on carbon rights when implementing REDD+ in Bangladesh. Abuse of discretion in the selection of person to receive trainings, to receive incentives and selection of personnel may occur during the implementation of REDD+. Diversion or embezzlement of REDD+ funds, money laundering and 
elite capture of REDD+ benefits are the major issues related to the financial management and benefit sharing in REDD+. Procurement management risks which may be occurred are overestimation of the costs and collusion between the politicians, investors and REDD+ implementers in the bidding or approval of contracts can be taken into consideration. The findings of this study are expected to contribute partially to the REDD+ strategy development by considering the possible potential risks during the implementation of REDD+ program in Bangladesh.

\section{Acknowledgement}

The study was conducted with the support of UNDP, Dhaka.

\section{References}

[1] UN-REDD, Bangladesh REDD+ Readiness Roadmap. Draft 1.3, 2012. Dhaka, Food and Agriculture Organization (FAO), United Nations Development Programme (UNDP), United Nations Environment Programme (UNEP).

[2] W.F. Laurance, Forest destruction in tropical Asia. Curr.Sci., 2007, 93(11), 1544.

[3] UNFCCC, Copenhagen accord. FCCC/CP/2009/L.7. 2009. United Nations Framework Convention on Climate Change (UNFCCC], Bonn, Germany.

[4] I.J. Visseren-Hamakers and P. Glasbergen, Partnerships in forest governance. Global Environ.Change, 2007, 17(3,4), 408.

[5] K. Bosselmann, R. Engel and P. Taylor, Governance for sustainability: Issues, Challenges, Success. IUCN Environmental Policy and Law, 2008.

[6] IPCC, Climate Change 2007: Synthesis Report. Cambride, UK and New York, USA, Cambridge University Press, 2007. 
Possible Corruption Risks to Successful Implementation of REDD+ In Bangladesh19

[7] B. Metz, O. Davidson, P. Bosch, R. Dave and L. Meyer, Climate Change 2007: Mitigation. Contribution of Working Group III to the Fourth Assessment Report of the Intergovernmental Panel on Climate Change, 2007.

[8] B.B.N. Strassburg, A. Kelly, A. Balmford, R.G. Davies, H.K. Gibbs, A. Lovett, L. Miles, C.D.L. Orme, J. Price, R.K. Turner and A.S.L. Rodrigues, Conservation Letters 2010, 3, 98.

[9] O. Venter, E. Meijaard, H. Possingham, R. Dennis, D. Sheil, S. Wich, L. Hovani and K. Wilson, Conservation Letters 2009, 2, 123.

[10] UNFCCC, Afforestation and Reforestation Projects under the Clean Development Mechanism: A reference manual. Bonn, Germany, UNFCCC, 2013.

[11] M. Colchester, Forest peoples, customary use and state forests: The case for reform. 11th Biennial congress of the international association for the study of common property, Bali, Indonesia 2006.

[12] L. Tacconi, M. Boscolo and D. Brack, National and International policies to control illegal forest activities. Report for the Ministry of Foreign Affairs, Government of Japan, Bogor, Indonesia, CIFOR, 2003.

[13] L. Tacconi, Illegal logging: Law enforcement, Livelihoods and the Timber Trade, Earthscan, London, 2007.

[14] A. Casson and K. Obidzinski, From new order to regional autonomy: Shifting dynamics of illegal logging in Kalimantan, Indonesia, Earthscan, London, 2007.

[15] J. Smith, K. Obidzinski, S. Subarudi and I. Suramenggala, Int. For. Rev., 2003, 5(3), 293.

[16] D. Southgate, P. Salazar-Canelos, C. Camacho-Saa and R. Stewart, World Dev, 2000, 28(11), 2005.

[17] TIB, Transparency and accountability in forest conservation and management: problems and way out. Dhaka, Transparency International, Bangladesh, 2008.

[18] M.S.H. Chowdhury and M.D. Miah, Journal of Forestry Research, 2003, 14(3), 253. 
20 Md. Danesh Miah and S. M. Raihan Abedin

[19] A.D. Capistrano and C.F. Kiker, Ecol. Econ., 1995, 14(1), 21.

[20] E.P. Flint, Chemosphere, 1994, 29(5), 1015.

[21] G. Rasul, G.B. Thapa and M.A. Zoebisch, Appl. Geogr, 2004, 24(3), 217.

[22] K.B. S. Rasheed, Geojournal, 1995, 37(1), 39.

[23] M.A. Salam, T. Noguchi and M. Koike, Geojournal, 1999, 47(4), 539.

[24] A. Angelsen, S. Brown, C. Loisel, L. Peskett, C. Streck and D. Zarin, Reducing emissions from deforestation and forest degradation : an options assessment report. Norway, Meridian Institute, The government of Norway, 2009.

Manuscript received on 22August, 2016, Revised manuscript received on 09 October, 2017 and accepted on 22 October, 2017

The Chittagong Univ. J. Sc. Vol. 41(1), 2019 